\title{
A Study on the Role of Ideological and Political Education in the Cultivation of Innovative Talents in Colleges and Universities
}

\author{
Dai Rui \\ Oxbridge College, Kunming University of Science and Technology, Kunming, Yunnan, China
}

Keywords: ideological and political education in colleges and universities; cultivation of innovative talents; role

\begin{abstract}
The growth and accumulation of innovative talents is the key to a country's prosperity and strength. The cultivation of innovative talents is a systematic project. The research on the status and role of ideological and political education in colleges and universities in cultivating innovative talents is of great significance to this system project.
\end{abstract}

\section{Introduction}

With the continuous development of society, the environment and challenges faced by ideological and political education in colleges and universities are also constantly changing. In order to cultivate innovative talents who adapt to the new era, ideological and political education in colleges and universities plays an important role.

\section{The Relationship between Ideological and Political Education and the Cultivation of Innovative Talents in Colleges and Universities}

\subsection{Differences in ideological and political education and the cultivation of innovative talents}

Ideological and political education means that certain classes, political parties, and social groups follow the rules of the formation and development of people's ideological morality, and use certain ideas, political views, and moral norms to exert a purposeful, planned, and organized influence on their members. Form social practice activities that meet the needs of a given society and a certain class.The ideological and political education in colleges and universities, however, uses education-centered practical activities to influence the formation and development of students' ideological morality and to make them consistent with the mainstream ideology of the society. The

Most innovative talents have rich professional knowledge, strong practical ability, and abundant creativity in their respective fields. Innovative talent is the most creative part of human society and a representative of advanced productive forces. The cultivation of innovative talents refers to the talented person education and training mode that enhances the overall quality of personnel while also focusing on improving the quality of innovation [1].

\subsection{Consistency between ideological and political education and the cultivation of innovative talents}

Many people ignore the internal connection between the ideological and political education and the cultivation of innovative talents in universities, and put the two in opposition. However, in fact, the ideological and political education in universities and the cultivation of innovative talents are intrinsically consistent. The cultivation of innovative talents is an inherent requirement of ideological and political education in universities. In 1996, the UNESCO report stated that "the task of education is to make all people's creative talent and creative potential bear fruitful results without exception". In order to adapt to the new trend of social development, we must reform the ideological and political education in colleges and universities. The cultivation of innovative talents meets the goals of ideological and political education in colleges and universities and is also an intrinsic requirement for ideological and political education in colleges and universities. Ideological 
and political education is very important in the university education system, and it plays an important role in cultivating innovative talents. The cultivation of innovative talents is not only the objective requirement for the training of higher education, but also the fundamental task of higher education. Many colleges and universities in our country lack the incentive system for innovative personnel training, which restricts the quality of innovative personnel training. Strengthening ideological and political education in universities can provide guarantee for the cultivation of innovative talents[2].Innovative personnel training formula is as follows.

$$
x_{i j}^{*}=\frac{x_{i j}-\bar{x}_{j}}{s_{j}} \quad i=1,2, \ldots, n ; j=1,2, \ldots, p
$$

\section{The Role of Ideological and Political education in Colleges and Universities in Cultivating Innovative Talents}

\subsection{To help foster innovative personality}

In addition to intelligence factors such as knowledge and skills, innovation capabilities also involve non-intellectual factors. Innovation ability requires not only relevant knowledge and capabilities as support but also non-intellectual factors such as innovative personality qualities as support. Innovative personality refers to the personality orientation and individual psychological characteristics of innovative subjects in their innovation activities. [3] The talent's ability to innovate is not just an ordinary intelligence factor, but is also related to the personality quality of talents. Ideological and political education can help innovative individuals recognize the establishment of a sense of subjectivity, thereby establishing a life attitude and spirit of innovation that are conducive to social development, thereby creating outstanding innovation personality.

\subsection{To help enhance the consciousness of innovation and innovative thinking}

With the rapid development of China's socialist modernization, the thinking and awareness of college students must also keep up with the pace of social development. This requires college students to use scientific thinking methods to understand problems and solve problems. College students should require real innovation in their studies and research. The ideological and political education in colleges and universities can provide the correct way of thinking for the innovation of college students, encourage them to give full play to their initiative, and enhance their innovative awareness and innovative thinking [3].

\subsection{To help create a good environment for innovation}

The cultivation and development of innovation and innovation are inseparable from the innovation environment. The ideological and political education in universities is to create an environment conducive to the talents of innovative talents. The ideological and political education in colleges and universities can comply with the requirements of the times and help students recognize the importance and urgency of innovation, and strive to form a good social environment that respects knowledge and talented people in the whole society and provide social environment support for the healthy growth of talents. The ideological and political education in colleges and universities provides a good platform for the cultivation and improvement of innovative thinking and innovative ability of college students, so that they can not only improve the level of knowledge theory in the process of practice, but also improve their ability to innovate.

\section{Ways of Ideological and Political Education in Colleges and Universities to Train Innovative Talents}

\subsection{Strengthen the role of ideological and political education in colleges and universities in cultivating innovative talents}

The ideological and political education in colleges and universities is a series of educational 
practice activities such as education of ideals and beliefs and patriotism education to help innovating individuals to correctly understand the essential social attributes of human beings and correctly understand the development laws of human society. The enrichment of human material achievements at the present stage is mainly due to the development of science and technology. However, the development of science and technology does not always bring benefits to humanity. Many disasters in modern society also come from modern science and technology. Having knowledge and innovative capabilities does not mean that they can be fully and correctly played and used to benefit humanity. If we only have high-tech innovations, but we do not have high-quality talents to master, it will be difficult to play its positive role and it may seriously endanger humanity and even cause unimaginable consequences. Comrade Jiang Zemin pointed out in his speech at the Third National Education Work Conference: "To speak of quality, ideological and political quality is the most important quality. Continuously enhancing the patriotism, collectivism, and socialist ideology of students and the masses is quality education. "Soul." Only ideological and political education that places great emphasis on innovative talents, bringing patriotism, collectivism, and socialist ideas into the conscious action of innovative talents can enable them to conscientiously consider the purpose of innovation when engaging in various innovative activities. And significance, to better play the positive role of technological innovation and curb its negative effects. Therefore, the ideological and political education in colleges and universities has the correct guiding role in cultivating innovative talents[4]. The innovative talent cultivation work pattern is as follows.

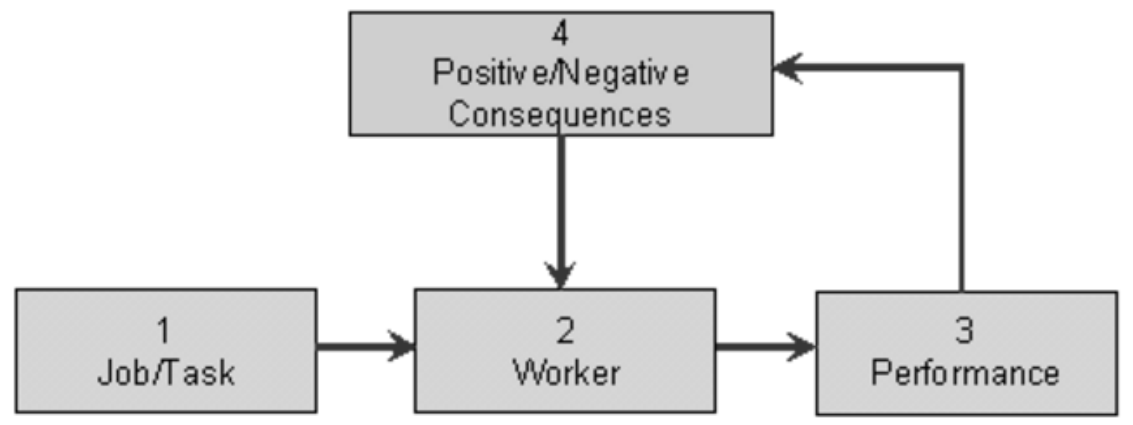

Fig.1 Innovative talent cultivation work pattern

\subsection{Strengthen ideological and political education in colleges and universities and focus on cultivating the innovative spirit of innovative talents}

The spirit of innovation means having the ability to use existing knowledge, information, skills, and methods, bring forward new methods, new ideas, and the will, confidence, courage, and wisdom to invent, innovate, and innovate. The spirit of innovation belongs to the category of scientific spirit and scientific thought. It is a psychological feature that must be possessed in carrying out innovative activities, including innovation awareness, interest in innovation, courage in innovation, determination in innovation, and related thinking activities. In the cultivation of innovative talents, people talk more about innovation. Innovation ability is indeed very important in the quality of innovative talents; but innovation ability is only one aspect of quality, not all of the quality of innovation. Just having the ability to innovate does not necessarily lead to innovation. In the innovative quality structure, the spirit of innovation is indispensable, and the spirit of innovation is even more important than the ability to innovate. Mental factors belong to the non-intellectual realm, and are more stable, lasting, and higher-level things in the non-intellectual realm than emotional factors. In the process of carrying out ideological and political education in colleges and universities, we must pay attention to the cultivation of innovative spirit, so that it will be more helpful for the cultivation of innovative talents.

\section{Summary}

An open, free environment and atmosphere is fertile ground for cultivating innovative talents. 
First of all, we must change the concept of traditional education. Historical materialism tells us that consciousness has an active counteraction to matter. The guidance of correct ideological concepts and strong ideological and political work have important guiding and directive roles in grasping the correct direction of educational innovation and reforming educational ideas. Second, we must do a good job of building academic style. Fair, democratic, free style of study is the basic prerequisite for achieving innovation. To innovate, we must leap over the traditional Leichi. Without a democratic and free learning atmosphere, we can't break through the paradox of traditional experience, and come up with new ideas, new ideas, and new methods. Only by upholding an equal research atmosphere, allowing different opinions to emerge, respecting various viewpoints and initiatives from all sides, can we fully mobilize the initiative of talents to promote and enhance the development of school innovation education. Only by sticking to the above two points and creating a good environment for fostering innovative qualities can we cultivate more and better innovative talents.

\section{References}

[1] Maitreesh Ghatak, Massimo Morelli, Tomas Sjöström. Entrepreneurial talent, occupational choice, and trickle up policies [J]. Journal of Economic Theory, 2016, 137(1).

[2] Katrin Mayer-Haug, Stuart Read,Jan Brinckmann, Nicholas Dew, Dietmar Grichnik. Entrepreneurial talent and venture performance: A meta-analytic investigation of SMEs [J]. Research Policy, 2013, 42(6-7).

[3] Weiying Zhang, W.W. Cooper, Honghui Deng, Barnett R. Parker, Timothy W. Ruefli. Entrepreneurial talent and economic development in China [J]. Socio-Economic Planning Sciences, 2010, 44(4).

[4] Kevin L. Johnson, Cindy Wu. Creating Entrepreneurial Opportunities as a Means to Maintain Entrepreneurial Talent in Corporations [J]. Journal of Small Business \&amp; Entrepreneurship, 2012, 25(3). 